\title{
NILAI PENDIDIKAN KARAKTER DALAM NOVEL ELIANA \\ KARYA TERE LIYE DAN RELEVANSINYA SEBAGAI BAHAN AJAR SASTRA DI SMA
}

\author{
Nanda Saputra \\ Sekolah Tinggi Ilmu Tarbiyah Al-Hilal Sigli \\ E-mail: Nandasaputra680@gmail.com
}

\begin{abstract}
ABSTRAK
Tujuan penelitian ini yaitu mendeskripsikan nilai pendidikan karakter pada novel Eliana Karya Tere Liye dan mendeskripsikan relevansiya sebagai bahan ajar di SMA. Metode penelitian ini adalah penelitian deskriptif kualitatif. Teknik pengumpulan data dalam penelitian ini yaitu pustaka, simak, dan catat. Data dianalisis menggunakan teknik analisis deskriptif kualitatif dengan penilaian dan deskripsi data yang telah diperoleh. Hasil dari penelitian ini adalah: (1) nilai pendidikan karakter dalam novel Eliana arya Tere Liye menggunakan pendekatan pragmatis yang meliputi nilai-nilai agama, kejujuran, disiplin, kerja keras, kreatif, mandiri, rasa ingin tahu, demokratis, menghargai prestasi, ramah /komunikatif, cinta damai, gemar membaca, peduli lingkungan, peduli sosial, dan tanggung jawab; dan (2) novel Eliana karya Tere Liye memiliki relevansi sebagai bahan ajar sastra di Sekolah Menengah Atas sesuai dengan silabus dan rencana pelajaran.
\end{abstract}

Kata Kunci: Karakter, Novel Eliana, Bahan Ajar

\section{A. PENDAhuluan}

Pendidikan karakter memiliki esensi dan makna yang sama dengan pendidikan moral dan pendidikan akhlak dengan tujuan membentuk pribadi anak, supaya menjadi manusia yang baik, warga masyarakat, dan warga negara yang baik (Gunawan 2014:24). Adapun kriteria manusia yang baik, warga masyarakat yang baik, dan warga negara yang baik bagi suatu masyarakat atau bangsa secara umum adalah nilai-nilai sosial tertentu yang banyak dipengaruhi oleh budaya masyarakat dan bangsanya.Oleh karena itu, hakikat pendidikan karakter dalam konteks pendidikan Indonesia adalah pendidikan nilai, yakni pendidikan nilainilai luhur yang bersumber dari budaya bangsa Indonesia sendiri dalam rangka membina kepribadian generasi muda.

Pendidikan karakter diwujudkan melalui nilai-nilai moral yang diimplementasikan untuk menjadi semacam nilai dalam diri kita yang akan melandasi dan dan perilaku. Nilai karakter tidak datang dengan sendirinya untuk membentuk nilai pendidikan karakter harus menanamkan kembali nilai-nilai dasar pendidikan karakter seperti nilai (religius, jujur, toleran, disiplin, kerja keras, kratif, demokratis, rasa ingin tahu, semangat kebangsaan, cinta tanah air, menghargai prestasi, bersahabat, cinta damai, gemar membaca, peduli lingkungan, peduli sosial, dan tanggung jawab) (Yaumi, 2018:83).

Mengingat pentingnya nilai-nilai pendidikan karakter untuk membangun generasi muda yang kuat, perlunya pendidikan karakter yang dilakukan dengan tepat. Pembentukan 
karakter sesuatu bangsa tidak dapat dipisahkan dalam kehidupan kita sehari-hari. Dengan demikian pendidikan karakter diintegrasikan ke seluruh aspek kehidupan, termasuk kehidupan sehari-hari, nilai pendidikan karakter dalam kehidupan sehari-hari dapat digambarkan melalui sebuah karya sastra yaitu novel.

Karya sastra merupakan media yang efisien untuk mengajarkan segala sesuatu seperti sains, nilai moral, nilai budi pekerti, dan nilai agama.Karya sastra berusaha menyampaikan nilai-nilai pendidikan yang merupakan refleksi dari kehidupan nyata sebagai hasil renungan realita kehidupan yang dilihat. Maka, karya sastra sangat diperlukan dalam kehidupan sebagai bahan pembelajaran moral.

Menurut Nurgiyantoro (2015:434-436), sastra mempunyai peran sebagai salah satu alat pendidikan yang seharusnya dimanfaatkan dalam dunia pendidikan, dan dalam penulisan ini dapat difokuskan pada peran dalam usaha untuk membentuk dan mengembangkan kepribadian anak, peran sebagai character building, artinya, sastra dapat diyakini mempunyai andil yang tidak kecil dalam usaha pembentukan dan pengembangan kepribadian anak. Karya sastra (novel) banyak dipergunakan sebagai sarana untuk mengajarkan berbagai keperluan hidup, memberikan ajaran moral, etika kehidupan, semangat perjuangan, mewariskan pandangan hidup, dan nilai-nilai diyakini kebenaran masyarakat (bangsa).

Novel sebagai salah satu bentuk karya sastra yang diharapkan dapat memunculkan nilai-nilai positif bagi pembacanya.Ketika dunia pendidikan dinilai hanya mementingkan ranah akademik semata, sehingga mengabaikan persoalan-persoalan moral dan keluhuran budi pekerti. Karya sastra novel yang berjudul Eliana karya Tere Liye, bisa menjadi perantara yang setrategis untuk mewujudkan tujuan untuk menanamkan nilai-nilai pendidikan karakter terhadap anak karena di dalam novel tersebut terdapat beberapa nilainilai pendidikan karakter yang dapat dijadikan pedoman untuk membentuk karakter anak.

Salah satu contoh media massa yang memiliki peran dalam nilai karakter kepada masyarakat adalah novel Eliana karya Tere-Liye. Di dalam Novel Eliana banyak pesan yang terkandung di dalamnya. Misalnya nilai karakter, nilai sosial, budaya, moral, dan sebagainya. Novel ini banyak sekali diminati oleh kalangan remaja maupun kalangan dewasa. Selain penulisnya yang terkenal, novel Eliana memang memiliki cerita yang sangat bagus, sehingga pembaca seperti dapat merasakan hal yang dibacanya. Novel ini mengisahkan Eliana seorang anak yang berpendidikan dan gigih dalam menggapai impiannya. Novel Eliana, memberikan sebuah pelajaran yang berharga dalam dunia pendidikan di sekolah, di keluarga maupun dilingkungan sekitar, agar generasi muda cinta terhadap tanah kelahirannya. Novel Eliana memberikan contoh untuk para orang tua dan pendidik dalam menghadapi kehidupan nyata yang akan datang. 
Berdasarkan penjelasan tersebut, novel Eliana karya Tere Liye berrelevansi dengan pembelajaran Bahasa Indonesia di Sekolah. Relevansi dapat dilihat pada silabus dan RPP yang terdapat pada pembelajaran Bahasa Indonesia di SMA. Relevansi pembelajaran novel masuk pada pembelajaran sastra terkait dengan unsur intrinsik dan unsur ekstrinsik novel. Unsur intrinsik novel yaitu tema, tokoh, penokohan, alur, setting, sudut pandang, gaya bahasa, dan amanat. Sedangkan unsur ekstrinsik novel yaitu sosial budaya, latar belakang pengarang, ekonomi, dan sebagainya.

\section{B. LANDASAN TEORI}

Novel berasal dari kata Latin novellus yang diturunkan dari kata novies yang berarti "baru". Dikatakan baru karena kalau dibandingkan dengan jenis-jenis sastra lainnya seperti puisi, drama dan lainnya (Tarigan, 1984: 164). Sebutan novel dalam bahasa Inggris yang kemudian masuk ke Indonesia dalam bahasa Itali novella dan dalam bahasa Jerman novella. Secara harfiah, novella berarti "sebuah barang baru yang kecil", yang kemudian diartikan sebagai "cerita pendek dalam bentuk prosa" (Nurgiyantoro, 2015: 11-12).

Novel juga diartikan sebagai cerita prosa fiktif yang melukiskan para tokoh, gerak sertaadegan yang dapat mewakili kehiduapan yang sebenarnya dalam suatu alur ataukeadaan yang sangat kacau. Selain pendapat tersebut, novel merupakan cuplikan dari kehidupan manusia dengan jangka yang lebih panjang dan menampilkan konflik-konflik yang menyebabkan perubahan pada setiap pelaku. Maka, novel mengandung nilai-nilai pendidikan yang dapat dijadikan teladan oleh masyarakat.

Berdasarkan pendapat tersebut, pendidikan karakter dimaknai sebagai tempat bagi kebebasan individu dalam menghayati nilai-nilai yang dianggap sebagai baik, luhur, dan layak diperjuangkan sebagai pedoman bertingkah laku bagi kehidupan pribadi berhadapan dengan dirinya, sesama dan Tuhan (Albertus, 2010:5). Selain itu, menurut Khan (2010:34) pendidikan karakter adalah proses kegiatan yang dilakukan dengan segala daya dan upaya secara sadar dan terencana untuk mengarahkan anak didik. Pendidikan karakter juga merupakan proses kegiatan yang mengarah pada peningkatan kualitas pendidikan dan pengembangan budi harmoni yang selalu mengajarkan, membimbing, dan membina setiap menusiauntuk memiliki kompetensi intelektual, karakter, dan keterampilan menarik.

Nilai-nilai pendidikan karakter yang dapat dihayati dalam penelitian ini adalah religius, nasionalis, cerdas, tanggung jawab, disiplin, mandiri, jujur, dan arif, hormat dan santun, dermawan, suka menolong, gotong-royong, percaya diri, kerja keras, tangguh, kreatif, kepemimpinan, demokratis, rendah hati, toleransi, solidaritas dan peduli. Menurut Gunawan (2012:23-24) pendidikan karakter memiliki esensi dan makna yang samadengan pendidikan moral dan pendidikan akhlak. Tujuannya adalah membentuk pribadi anak, supaya menjadi manusia yang baik, warga masyarakat yang baik,dan warga Negara yang 
baik.Adapun kriteria manusia yang baik, warga masyarakat yang baik, dan warga Negara yang baik bagi suatu masyarakat atau bangsa, secara umum adalah nilai-nilai sosial tertentuyang banyak dipengaruhi oleh budaya masyarakat dan bangsanya.Oleh karena itu, hakikat pendidikan karakter dalam konteks pendidikan Indonesia adalah pendidikan nilai, yakni pendidikan nilai-nilai luhur yang bersumber dari budaya bangsa Indonesia sendiri, dalam rangka membina kepribadian generasi muda.

Pendidikan karakter juga dapat dimaknai sebagai upaya yang terencana untuk menjadikan peserta didik mengenal, peduli, dan menginternalisasikan nilai-nilai sehingga peserta didik menjadi insan kamil. Pendidikan karakter juga dapat diartikan sebagai suatu sistem penanaman nilai-nilai karakter kepada warga sekolah yang meliputi komponen pengetahuan, kesadaran atau kemauan dan tindakan untuk melaksanakan nilai-nilai tersebut baik terhadap Tuhan Yang Maha Esa, diri sendiri, sesana, lingkungan maupun kebangsaan sehingga menjadi manusia yang sempurna. Penanaman nilai pada warga sekolah maknanya bahwa pendidikan karakter baru akan efektif jika tidak hanya siswa, tetapi juga para guru, kepala sekolah dan tenaga non-pendidik disekolah harus terlibat dalam pendidikan karakter. Pendidikan karakter adalah proses menanamkan karakter tertentu sekaligus memberi benih agar peserta didik mampu menumbuhkan karakter khasnya padasaat menjalankan kehidupan. Dengan kata lain, peserta didik tidak hanya memahami pendidikan sebagai bentuk pengetahuan, namun juga menjadikan sebagai bagian dari hidup dan secara sadar hidup berdasarkan pada nilai tersebut.

Pendidikan karakter dalam pembelajaran sastra digunakan sebagai bahan ajar oleh guru. Guru yang baik harus dapat menampilkan bahan ajar yang menyenangkan. Guru harus mencari cara untuk membuat pembelajaran menjadi menyenangkan dan mengesampingkan ancaman selama proses pembelajaran. Salah satu cara untuk membuat pembelajaran menjadi menyenangkan adalah dengan menggunakan bahan ajar yang relevan dan konkret sesuai dengan pembelajaran. Bahan ajar yang dapat digunakan oleh guru dalam pembelajaran sastra yaitu menghadirkan buku-buku novel yang sesuai dengan bahan ajar.

Menurut Prastowo (2012:17) bahan ajar pada dasarnya merupakan segala bahan (baik informasi, alat, maupun teks) yang disusun secara sistematis, yang menampilkan sosok utuh dari kompetensi yang akan dikuasai siswa dan digunakan dalam proses pembelajaran dengan tujuan perencanaan dan penelaahan implementasi pembelajaran.

Bahan pengajaran adalah sesuatu yang mengandung pesan yang akan disajikan dalam proses belajar mengajar (Ismawati, 2010:91). Bahan pengajaran sastra harus dipilih dengan tepat, beberapa aspek perlu dipertimbangkan dalam memilih bahan pengajaran sastra. Selain itu, bahan ajar merupakan seperangkat bahan pelajaran yang dapat membantu 
tercapainya tujuan kurikulumyang disusun secara sistematis dan utuh sehingga tercipta lingkungan belajar yangmenyenangkan, memudahkan siswa belajar, dan guru mengajar.

\section{METODE PENELITIAN}

Penelitian ini menggunanakan jenis penelitian kualitatif. Penelitian kualitatif merupakan penelitian yang dimaksudkan untuk memahami fenomena tentang apa yang dialami oleh subjek penelitian yang berupa perilaku, persepsi, motivasi, tindakan, dan lainlain. Secara holistik dan dengan cara deskripsi dalam bentuk kata-kata dan bahasa pada suatu konteks khusus yang alamiah dan memanfaatkan metode alamiah (Moleong, 2013:6).

Penelitian ini menggunakan metode penelitian deskriptif kualitatif dengan menggunakan pendekatan semiotika dengan menggunakan analisis isi. Data dalam penelitian ini berwujud kalimat, dan paragraf yang berkaitan dengan nilai-nilai pendidikan karakter dalam novel Eliana Karya Tere Liye dan implementasinya dalam bahan pembelajaran Bahasa Indonesiadi SMA. Sumber data penelitian ini berupa novel dan silabus mata pelajaran Bahasa Indonesia di SMA kelas XII. Teknik pengumpulan data dalam penelitian ini yaitu pustaka, simak, dan catat. Teknik keabsahan data menggunakan teknik triangulasi teori. Teknik analisis datadigunakan dalam penelitian ini adalah teknik kualitatif yang bersifat mengidentifikasi, menganalisis, dan memaparkan.

\section{HASIL PENELITIAN DAN PEMBAHASAN}

Sesuai dengan tujuan penelitian, maka terdapat nilai pendidikan karakter dalam novel Eliana karya Tere Liyedengan menggunakan pendekatan semiotik dan relevansi novel Elianakarya Tere Liye terhadap bahan ajar sastra di SMA.

\section{Nilai Pendidikan Karakter dalam Novel Eliana}

a. Religius

Religius merupakan sikap dan perilaku yang patuh dalam melaksanakan ajaran Agama yang dianutnya, toleran dalam pelaksanaan ibadah agama lain dan hidup rukun dengan pemeluk agama lain. Adapun nilai karakter religius yang terkandung dalam novel Eliana sebagai berikut.

1) Mengucapkan salam

"Awalnya, mamak versi muda memberanikan diri mengintip bapak yang datang mendorong sepeda tua, parkir di halaman sebelah. Mengintip bapak yang melangkah menuju tangga depan. Mendengar lamat-lamat suara salam dari depan rumah. Mamak juga mengintip lewat celah-celah papan saat Bapak pulang dua jam kemudian". 
Berdasarkan teks di atas, terkandung makna bahwa sebelum memasuki rumah orang lain ataupun bertemu dengan sesama muslim, Bapak selalu mengucapkan "assalamu"ealaikum".

2) Salat

"Kebetulan kau ke dapur. Tadi mamak kira kalian sudah tidur.Tolong kau gantikan mamak mengaduk kuali ini. Mamak mau ganti baju, belum salat isya"

(NR.4) "Sorenya, lepas salat magrib, melipat mukena, aku beranjak ke dapur. Perutku lapar. Di meja makan sudah ada Amelia yang menunggu sambil asyik memperhatikan Bapak mengaduk kopi.Mamak sedang sibuk dengan centong nasi."

Salat merupakan kewajiban seorang muslim. Salat merupakan cara beribadah seorang muslim. Tokoh yang digambarkan rajin salat karena kewajiban sebagai seorang muslim.

\section{3) Rasa Bersyukur}

"Perkenankan kami memperkenalkan diri.Nama saya Syahdan, mewakili petani dari lembah Bukit Barisan pulau Sumatra.Tanah di lahan kami amat subur, kami menanam kopi dan karet.Puji syukur pada yang maha Kuasa, tahun ini hasil panen kopi kami berlimpah ruah."

Penggalan cerita di atas, diketahui bahwasanya di dalam cerita muncul orang yang bersifat sabar, penyayang, dan taat kepada Allah Swt. Terbukti dari kalimat “ Puji Syukur Kepada Tuhan Yang Maha Kuasa” yang artinya, di dalam cerita, menceritakan rasa syukur seseorang dengan apa yang telah diraihnya. Sehingga orang tidak lupa kepada sang penciptanya, entah dalam keadaan susah maupun senang.

b. Toleransi

Toleransi dapat di artikan suatu sikap saling menghormati dan menghargai antar kelompok atau antar individu dalam lingkungan masyarakat. Hal ini terlihat pada kutipan data berikut ini.

"Aku berkenalan dengan banyak murid dari berbagai sekolah. Mereka datang dari segala penjuru Indonesia. Dari sekolah-sekolah terbaik."

"Menyenangkan mendengar mereka bercerita. Bangunan sekolah yang bagus, buku-buku perpustakaan yang banyak, guru-guru yang pintar, kegiatan sekolah yang hebat.Aku tidak cemburu."

"Aku hanya membayangkan alangkah senangnya jika kelak aku bisa melanjutkan sekolah di tempat seperti itu. Sebagai tukarnya, aku menceritakan kampung kami, hutan-hutan kami, sungai, lembah."'Mereka menatapku penuh rasa ingin tahu.Pak Bin benar, ada banyak hal yang bisa kami banggakan."

Penggalan cerita di atas tampak jelas menunjukkan bahwa toleransi terpancar dari berbagai tokoh. Walaupun Eliana dan teman-teman berasal dari sekolah yang berada di pedalaman dan bukan sekolah favorit, mereka yang berasal dari sekolah kabupaten maupun sekolah provinsi yang menjadi sekolah favorit memiliki rasa toleransi yang sangat tinggi.Secara bergantian, mereka 
bertukar cerita tentang pengalaman-pengalaman dari kampung halaman masing-masing, berbagai topik mereka saling bertukar cerita. Oleh karena itu, Eliana dan teman-teman yang berasal dari sekolah pedalaman sangat senang mengikuti kegiatan tersebut. Saling menghargai memang sangat penting untuk dipahami anak-anak sejak dini.

c. Semangat Kebangsaan

"Kita tak bisa mengusir mereka, Pendi."Mang Dullah menggeleng." "Kenapa tidak Mang?Sepanjang kita kompak, para penambang itu bisa di suruh pergi. Enam bulan lalu,, ramai-ramai kita bisa menyuruh mereka angkat kaki." Pendi, salah satu pemuda desa mengepal tinju. Beberapa warga lain yang ikut pertemuan berseruseru sepakat menanggapi Pendi, mengangguk satu sama lain."

"Pertemuan di balai kampung berakhir tanpa simpulan.Aku, Damdas dan Hima yang sejak pulang mengaji, sembunyisembunyi ikut menguping pembicaraan segera berlarian pulang sebelum ketahuan.Hima dan Damdas juga mendenggus kesal mendengar hasil pertemuan.Sementara aku sambil berlarilari kecil, mendongak menatap bulan separuh.Kalimat Wak Yati mengiang di kepalaku, "hukum sampah mereka."

Penggalan di atas, tampak Tere Liye memunculkan semangat kebangsaan yang dibawai oleh jiwa anak-anak. Seperti pada pernyataan “ sepanjang kita kompak, pasti para penambang itu akan pergi" mereka benar-benar melindungi hutan, sungai yang ada di lingkungan mereka. Begitulah semangat kebangsaan muncul, yaitu untuk melindungi aset-aset negara yang disalahgunakan.

d. Cinta Tanah Air

"Domme wetten, mereka bilang apa? Sesuai hukum? Hukum apa yang mereka maksud? Hukum sampah mereka? Suara serak Wak Yati terdengar di langit-langit balai pertemuan, " mereka telah mengutak-atik hukum agar sesuai keinginan jidat. Gosh, baca kitab undang-undang Belanda, sungai adalah wilayah terlarang untuk aktivitas pertambangan. Haram hukumnya menyentuh sungai.Mereka pastilah menyumpal mulut pihak berkepentingan untuk mendapatkan izin lengkap mengeduk pasir.Dan lebih banyak lagi untuk menyumpal petugas yang bersedia menjaga tambang."'Peserta pertemuan diam."

"Dua minggu sebelum negosiasi ulang izin tambang pasir, kami berempat terus berkeliling.Tanda tangan di kertas penolakan semakin banyak.Sudah Sembilan lembar siapa saja.Bahkan Paman Unus yang sedang berkunjung ke sekolah, memeriksa kondisi terakhir plafon yang diperbaiki pekerjaannya, apakah ada bocor atau tidak."

Penggalan cerita di atas, terlihat kepahaman Wak Yati dalam menyampaikan ketidakadilan hukum yang ada. Ketika anak-anak kecil dan para tetua-tetua desa telah berusaha mengambil alih, namun apa daya apabila undang-undang tidak berlaku lagi. Susah bagi mereka dengan keterbatasan uang yang dimiliki untuk mampu berjalan tanpa rintangan. Namun, semangat kami dalam cinta tanah air, akan terus terwujud dengan berbagai cara yang bisa kami lakukan. 


\section{e. Peduli Lingkungan}

"Dua minggu menjelang negosiasi ulang izin tambang pasir "Kami empat buntal mulai menanyai seluruh penduduk kampung pendapat mereka tentang tambang pasir inilah pendekatan baru dari empat buntal mengumpulkan informasi menyamakan cita-cita pendapat belajar bersama-sama."

"Wak Yati bersungut-sungut jangan tanyatanya soal hukum peraturan undang-undang atau apalah itu pada bahwa kau ini Eli kau kalau kau tanya soal bagaimana berladang atau mengambil madu di sarangnya aku tahu yang paham urusan ini justru bapak kau atau Dullah ada-ada saja hanya pernah tertawa saja tidak perlu salahin aku meriksa eh kami sekedar ingin tahu pendapat bahwa aku menggaruk kepala yang tidak gatal.

Penggalan cerita di atas memunculkan rasa peduli lingkungan dengan cara melalui pendekatan survei bahwa masyarakat tidak setuju dengan adanya pertambangan pasir di tempat tersebut. Eliana sejak kecil telah berani dan cerdas menanggapi orangorang kota yang merusak alam dan mampu peduli terhadap lingkungannya. Bentuk kesadaran Eliana dan teman-teman telah muncul sejak dini, serta membawa dampak positif untuk lingkungannya.

\section{f. Menghargai Prestasi}

"Itu karena kau anak sulung Eli.Bapak akhirnya berkata setelah lengang sejenak." "Mamak berharap banyak pada kau menjadi teladan yang baik bagi adik-adikmu memberikan contoh tidak mungkin pekerjaan memberikan panutan sepenting itu ditempatkan pada berlian pukat apalagi Amelia hanya pada kau anak paling pemberani di keluarga ini kau saja yang tidak tahu alasannya belum mengerti apa maksud semua omelan Mamak. Lagipula bukankah menyenangkan menjadi anak sulung kau selalu yang selalu diajak kemana-mana ke kota Provinsi mencari ikan ke hutan dan sebagainya kau juga tidak perlu seperti Amelia yang menerima baju lungsuran. Oi kau adalah anak sulung semua harapan dan mimpi mimpi Mamak ada padamu bagaimana mungkin Mamak tidak sayang."

Menghargai prestasi tampak terlihat oleh Bapak yang diberikan untuk Anak sulungnya yaitu, Eliana.Ketika Eliana memiliki kewajiban untuk membantu orang tua dalam mengasuh adik-adiknya.Ketika itu terjadi sebuah masalah.Ia terkena marah oleh Mamaknya. Namun, Bapak yang sabar mampu membuat itu semua menjadi apresiasi bahwa tidak semua kehidupan akan berjalan mulus, akan ada kerikil-kerikil yang bisa membuat orang terjatuh. Walaupun begitu, Bapak tetap memberi semangat dan memberi apresiasi ke Eliana akan hal yang terjadi sebagai peringatan untuk pembelajaran di hari selanjutnya.

\section{g. Kerja Keras}

"Kami perlahan menyeberangi aliran air kemudian menyusuri tepi sungai seberang berhulu dan langit semakin gelap gemuruh, Guntur semakin sering, angin malam terasa semakin dingin, aku merapatkan jaket yang kupinjam dari kamar Bapak." 
"Kami melewati beberapa ladang jagung lagi hingga bertemu hutan lebat. Kami bertiga hati-hati melalui jalan setapak yang persis berada di tepi sungai dengan cara setinggi 3 meter di sebelah kiri kami ada pohon-pohon tinggi menjulang, hutan rimba di sebelah kanan adalah rumput yang amat terkenal di seluruh kampung lubuk larangan."

Penggalan di atas, diketahui bahwa Eliana bersama ketiga temannya memulai misi yang telah mereka rencanakan dalam beberapa hari terakhir. Dengan semangat juang tinggi serta kerja keras dalam mengumpulkan keberanian, mereka memulai aksinya.

h. Kreatif

"Pak Bin memulai pelajaran IPS pagi itu dengan cara menyenangkan, "kalian sudah mengerjakan PR dengan baik, bukan?" Beliau bertanya lantang, kami mengangguk, "Nah, kita akan melakukan permainan kecil."Teman-teman menatap kedepan antusias."" Kita sebut permainan dengan nama 'tebakan berantai'.... Bapak akan memilih salah satu di antara kalian, menyebut sembarang nama negara. Kalian yang terpilih harus menebak nama ibu kota negara yang Bapak sebut."

Penggalan cerita di atas, tampak terlihat kreativitas muncul dari seorang guru yang bernama Pak Bin.Beliau mengajar dengan begitu menyenangkan, yaitu belajar sambil bermain. Hal tersebut membutuhkan sebuah kekreativitasan agar dalam mengelola kelas dapat berjalan dengan lancar, seluruh murid memperhatikan, dan paham akan bahan yang telah disampaikan.

i. Jujur

"Sebenarnya guci itu aku yang merusaknya.Tidak sengaja tersenggol saat membersihkan tikar pandan, jatuh, gompal mulut gucinya.Tadi bersama Burlian segera kurekatkan kembali seadanya dengan lem plastik, berharap Mamak tidak tahu.Sayangnya, Mamak super teliti, ketahuan”.

Penggalan cerita di atas, tampak bahwa kejujuran disampaikan langsung dalam dialog oleh tokoh yang bernama Pukat dan Burlian, yaitu mengakui atas kesalahan yang telah diperbuat oleh dirinya. Mengatakan hal yang sesungguhnya terjadi adalah mengatakan kebenaran dari yang tokoh alami, serta tidak menyembunyikan atas kesalahan yang telah terjadi.Selain dari penggalan cerita tersebut.Tere liye kembali memunculkan tokoh dengan kebiasan jujur dan tidak berbohong.

j. Peduli Sosial

"Eli, tolong kumpulkan PR kawan-kawan kau."“Aku mengangguk, segera berdiri, sigap mendatangi meja teman-temanku.Beberapa lancar menyerahkan bukunya.Beberapa pasrah.Beberapa sedikit mengeluh.Ada juga yang menolak". 
Pada penggalan teks di atas, menunjukkan sikap peduli sosial yang dilakukan tokoh Eliana dalam novel, yaitu peduli akan orang yang berada di sekitarnya dengan sikap tolong menolong sesuai dengan permintaan tolong yang dilontarkan oleh Guru kepada muridnya. Peduli sosial memang harus diajarkan kepada anak sejak dini mungkin.Sebab, karakter anak terbentuk sejak dini. Apabila pendidikan yang didapatkan anak sejak dini bagus, bagus pula hasil yang akan dipetik oleh orang tua.

k. Rasa Ingin Tahu

" Kau temukan dimana batu-batu ini? Aku menatap Marhotap, ingin tau."'Rahasia.Marhotap menjawab dengan intonasi menyebalkan."'Di mana?Hulu sungai?Pemandian?" "Percuma, aku tidak akan memberi tahu kau. Marhotap nyengir."“'Ayolah, kau temukan di mana?"Aku memohon."Marhotap hanya menatapku kasihan".

Penggalan cerita di atas, tampak jelas menunjukkan rasa ingin tahu Eliana terkait batu-batu cantik nan antik yang dimiliki Marhotap. Ketidakpuasaan Eliana atas jawaban yang diberikan Marhotap padanya, membuat Eliana terus menerus bertanya dengan pertanyaan yang mendesak.Eliana terus mencoba mengetahui asal batu-batu tersebut di temukan oleh Marhotap.Hal ini menunjukkan bahwa tokoh Eliana memiliki rasa ingin tahu yang tinggi. Rasa ingin tahu akan selalu muncul pada setiap orang ketika mereka ingin mengetahui sesuatu hal yang mereka belum tahu.

1. Disiplin jari."

"Waktunya habis anak-anak.Pak Bin mengetuk meja dengan belakang

Beberapa teman panik, di belakangku Damdas masih terus menulis.

"Waktunya habis, anak-anak.Selesai-tidak selesai kumpulkan.

Sikap disiplin merupakan sikap yang patuh terhadap komitmen. Sikap disiplin harus ditunjukkan sebagai upaya untuk menwujudkan komitmen yang telah dibangun. Sikap disiplin dapat menghantarkan seseorang dalam gerbang kesuksesan. Sikap disiplin ditunjukkan pada tokoh Damdas yang mengerjakan tugas sesuai dengan arahan guru.

m. Mandiri

"Besok pagi aku akan berangkat ke kota provinsi menumpang kereta.Boleh jadi butuh dua-tiga hari di sana untuk bertemu dengan teman lama yang bisa membantu." "Maaf kali ini aku tidak bisa menemani”" "Tidak masalah Pak Bin.”

"Sepagi ini, hatiku masih sebal.Nasihat Bapak tidak membantu banyak.Aku bahkan tidak berselera menghabiskan sarapan. Tetapi dengan semua perasaan marah dan sakit hati itu, aku akan menunjukkan kepada Mamak, kalau aku cukup becus menjadi Kakak sulung dari adik-adikku. Aku 
memutuskan akan "melawan" semua omelan Mamak dengan mengurus semua adik-adikku sebaik mungkin."

Pada penggalan cerita di atas, tampak terlihat kemandirian yang dilakukan Bapak Eliana yang bernama Syahdan dalam bersikap mandiri menghadapi sebuah perencanaan.Kemudian, sifat kemandirian tersebut diwarisi oleh anaknya yang bernama Eliana ketika menghadapi masalah Eliana berusaha dalam menyelesaikan dengan santai tanpa mengurangi kewajibannya sebagai anak sulung.

n. Tanggung Jawab

"maaf kali ini aku tidak bisa menemani" "Tidak masalah pak Bin. Sekolah tidak bisa ditinggalkan.Pendidikan anak-anak jauh lebih penting. Dengan pendidikan yang baik, merekalah yang akan memastikan seberapa lama kita bertahan menghadapi kerakusan orang-orang kota".

Penggalan cerita di atas, menjelaskan situasi pada saat para pemberani desa ingin memperjuangkan daerah mereka. Namun, Pak Bin memiliki tanggung jawab yang besar akan pendidikan anak-anak didiknya sehingga pada kali itu, Pak Bin tidak dapat ikut pergi ke kota Provinsi. Rasa tanggung jawab sangat terlihat dari pernyataan Pak Bin yang beralasan “ Maaf kali ini tidak bisa menemani”. Sebab, guru yang ada di sekolah tersebut memang hanya tiga.Rasa tanggung jawab tersebutlah yang harus menjadi contoh bagi para generasi muda untuk selalu mengerjakan segala sesuatu yang telah menjadi kewajibannya.

o. Bersahabat/Komunikatif

"Aku juga membenci truk-truk pasir itu. Marhotap bercerita di sepanjang jalan setapak menuju kampung, gara-gara mereka, air keruh bercampur pasir menutupi permukaan lubuk."

Aku dan Hima diam, tidak banyak menyela ceritanya.Setelah lima belas menit kaki Damdas yang keseleo bisa digerakkan mesti tertatih.

Penggalan cerita di atas, terlihat bahwa Eliana dan teman-teman mendengarkan dengan baik apa yang diucapkan Marhotap. Sikap yang di tunjukkan Eliana dan teman-temannya adalah sikap saling menghargai, serta menunjukkan rasa persahabatan yang tinggi diantara mereka.

p. Demokratis

"Eli ingin kita lebih kompak. Punya pemahaman yang sama tentang tambang, kompak menyikapi para perusak hutan, sungai, dan lembah di kampung kita. Eli ingin "Empat Buntal" belajar banyak hal tentang mereka, bertanya pada orang-orang yang mengerti." 
Pada penggalan cerita di atas, Eliana menginginkan kekompakan muncul di antara mereka tanpa ada pengecualian spesial kepada salah seorang teman.Agar misi yang telah mereka rancang mampu berjalan dengan baik.

q. Cinta Damai

"Kau duluan yang cerita Amel, nanti giliran Kakak kau yang cerita."Bapak menengahi, tersenyum, "Biar kita dengarkan dari dua pihak yang bertengkar." Amelia terisak, menyeka pipi "Ayo, Amel ceritakan." Amelia mengangguk.Lantas dengan suara tersendat-sendat mulai bercerita."

Penggalan teks di atas menunjukkan bahwa seorang Bapak yang bersifat lemah lembut sedang mendinginkan suasana yang ada di rumahnya dengan melerai Eliana dan Amelia untuk mencari tahu asal kesalahan yang terjadi.Bapak mulai menengahi dengan mengulang kembali kejadian yang telah berlalu agar saling bisa mengoreksi diri.Dari penggalan cerita tersebut, diketahui bahwa rasa cinta damai muncul dari orang yang memulai melerai antara dua orang.

r. Gemar Membaca

"Aku bingung, tanganku gemetar memegang kitab di dada.Obor kerlapkerlip di terpa angin malam.Kakiku gemetar oleh perasaanyang tidak kupahami. Setelah lima menit menatap gelap depanku, aku berjalan pulang, menyusul Amelia, Burlian, dan Pukat. Tiba di rumah, Bapak tidak ada, sedang pergi ke rumah Pak Bin."

Penggalan cerita di atas, diketahui bahwa kegiatan sehari-hari Eliana dan anak-anak yang lain adalah mengaji atau membaca Al-quran di setiap sorenya di rumah Nek Kiba. Mereka telah di didik untuk belajar mengaji sejak dini agar kelak besarnya dapat menjadi anak yang saleh dan saleha.

\section{Relevansi Novel Eliana Karya Tere Liye sebagai Bahan Ajar Sastra di SMA}

Novel Eliana Karya Tere Liye mempunyai relevansi dalam bahan pembelajaran Bahasa Indonesia di sekolah, mengenai pembelajaran menganalisis novel di kelas XII SMA. Disesuaikan silabus dan RPP Bahasa Indonesia dengan adanya Kompetensi Dasar (KD) tentang pembelajaran sastra pada kurikulum 2013, yang lebih relevan sebagai bahan ajar dengan penelitian ini adalah Kompetensi Dasar (KD) 3.3 Menganalisis teks novel baik melalui lisan maupun tulisan. Oleh karena itu, novel tersebut berelevansi untuk dijadikan sebagai bahan ajar pada kelas XII SMA.Dengan Kompetensi Dasar (KD) tersebut, dapat menganalisis teks novel dengan struktur intrinsik maupun ekstrinsik.Struktur intrinsik meliputi alut/plot, tokoh dan penokohan, latar/setting, sudut pandang, bahasa/gaya bahasa, tema, dan amanat.Dan struktur ekstrinsik meliputi nilai pendidikan karakter yang dapat 
diterapkan sebagai bahan ajar di sekolah untuk menemukan nilai-nilai yang terdapat dalam novel tersebut.

Nilai pendidikan karakter dalam novel Eliana Karya Tere Liyemeliputi nilai religius, jujur, disiplin, kerja keras, kreatif,mandiri, demokratis, rasa ingin tahu, menghargai pretasi, bersahabat/komunikatif, cinta damai, gemar membaca, peduli lingkungan, peduli sosial, dan tanggung jawab. Melalui nilai-nilai tersebut, peserta didik diharapkan mampu menerapkannya yang terkandung dalam novel Eliana agar menjadikan peserta didik sebagai pribadi yang lebih baik.

Hasil penelitian ini menunjukkan bahwa novel Eliana Karya Tere Liye sesuai sebagai bahan pembelajaran sastra di SMA, karena novel ini banyak memunculkan nilai-nilai pembelajaran dalam pendidikan karakter yang dapat diteladani peserta didik maupun dalam menjalani hidup.Novel ini juga mengisahkan tentang pendidikan, terdapat nilai-nilai pendidikan karakter yang terkandung tokoh.Oleh karena itu, novel Eliana Karya Tere Liyedapat dijadikan bacaan wajib peserta didik dalam pembelajaran sastra dan juga cocok dibaca untuk semua kalangan.

\section{E. DAFTAR PUSTAKA}

Albertus, Doni Koesoema. 2010. Pendidikan Karakter Strategi Mendidik Anak di Zaman Global. Jakarta: PT.Grasindo.

Gunawan, Heri. 2012. Pendidikan Karakter Konsep dan Implementasi.Bandung:Alfabeta.

Liye, Tere. 2011. Eliana Serial Anak-Anak Mamak. Jakarta: Republika Penerbit.

Moelong, Lexy J. 2013. Metodologi Penelitian Kualitatif. Bandung: Remaja Rosdakarya.

Nurgiyantoro, Burhan. 2015. Teori Pengkajian Fiksi. Yogyakarta: Gadjah Mada University Press.

Prastowo, Andi. 2012. Panduan Kreatif Membuat Bahan Ajar Inovatif. Jogjakarta: Diva Press

Khan, Yahya. 2010.Pendidikan Karakter Berbasis Potensi Diri. Yogyakarta: Pelangi Publishing.

Yaumi, Muhammad. 2016. Pendidikan Karakter Landasan, Pilar, dan Implementasi. Jakarta: Prenadamedia Group. 